\title{
The metabolic syndrome in mice overexpressing neuropeptide $Y$ in noradrenergic neurons
}

\author{
Liisa Ailanen', Suvi T Ruohonen², Laura H Vähätalo² , Katja Tuomainen², Kim Eerola², \\ Henriikka Salomäki-Myftari', Matias Röyttä3, Asta Laiho4, Markku Ahotupa5, \\ Helena Gylling ${ }^{6}$ and Eriika Savontaus ${ }^{7}$
}

${ }^{1}$ Institute of Biomedicine and Turku Center for Disease Modelling; Drug Research Doctoral Program, University of Turku, Turku, Finland

Institute of Biomedicine and Turku Center for Disease Modelling, University of Turku, Turku, Finland ${ }^{3}$ Department of Pathology, University of Turku and Turku University Hospital, Turku, Finland 4Turku Centre for Biotechnology, University of Turku and Åbo Akademi University, Turku, Finland ${ }^{5}$ Research Centre of Applied and Preventive Cardiovascular Medicine, University of Turku, Turku, Finland ${ }^{6}$ Department of Internal Medicine, University of Helsinki and Helsinki University Central Hospital, Helsinki, Finland

${ }^{7}$ Institute of Biomedicine and Turku Center for Disease Modelling, University of Turku; Turku University Hospital, Unit of Clinical Pharmacology, Turku, Finland

\author{
Correspondence \\ should be addressed \\ to E Savontaus \\ Email \\ eriika.savontaus@utu.fi
}

\begin{abstract}
A gain-of-function polymorphism in human neuropeptide Y (NPY) gene (rs16139) associates with metabolic disorders and earlier onset of type 2 diabetes (T2D). Similarly, mice overexpressing NPY in noradrenergic neurons (OE-NPYDBH) display obesity and impaired glucose metabolism. In this study, the metabolic syndrome-like phenotype was characterized and mechanisms of impaired hepatic fatty acid, cholesterol and glucose metabolism in pre-obese (2-month-old) and obese (4-7-month-old) OE-NPYDBH mice were elucidated. Susceptibility to T2D was assessed by subjecting mice to high caloric diet combined with low-dose streptozotocin. Contribution of hepatic Y1-receptor to the phenotype was studied using chronic treatment with an Y1-receptor antagonist, BIBO3304. Obese OE-NPYDBH mice displayed hepatosteatosis and hypercholesterolemia preceded by decreased fatty acid oxidation and accelerated cholesterol synthesis. Hyperinsulinemia in early obese state inhibited pyruvate- and glucose-induced hyperglycemia, and deterioration of glucose metabolism of OE-NPYDBH mice developed with aging. Furthermore, streptozotocin induced T2D only in OE-NPYDBH mice. Hepatic inflammation was not morphologically visible, but upregulated hepatic anti-inflammatory pathways and increased 8-isoprostane combined with increased serum resistin and decreased interleukin 10 pointed to increased NPY-induced oxidative stress that may predispose OE-NPYDBH mice to insulin resistance. Chronic treatment with BIBO3304 did not improve the metabolic status of OE-NPYDBH mice. Instead, downregulation of beta-1-adrenoceptors suggests indirect actions of NPY via inhibition of sympathetic nervous system. In conclusion, changes in hepatic fatty acid, cholesterol and glucose metabolism favoring energy storage contribute to the development of NPY-induced metabolic syndrome, and the effect is likely mediated by changes in sympathetic nervous system activity.
\end{abstract}

\footnotetext{
Key Words

- neuropeptide $Y$

- hepatic cholesterol synthesis oxidative stress

- glucose metabolism

- type 2 diabetes NAFLD

- Y1-receptor
}

() 2017 Society for Endocrinology Printed in Great Britain
Published by Bioscientifica Ltd
Journal of Endocrinology

(2017) 234, 57-72 


\section{Introduction}

Besides its orexigenic nature in the hypothalamus (Zarjevski et al. 1993, Yang et al. 2009, Sousa-Ferreira et al . 2011), neuropeptide Y (NPY) induces obesity and metabolic alterations independent of hyperphagia. In humans, a gain-of-function polymorphism in NPY gene (rs16139, p.L7P), which increases NPY secretion especially upon sympathetic activation (Kallio et al. 2001, Mitchell et al. 2008), has been associated with traits of the metabolic syndrome, i.e. weight gain, hypercholesterolemia, impaired glucose tolerance (IGT), insulin resistance (IR), earlier onset of type 2 diabetes (T2D) and increased risk of diabetes-related vascular complications (Karvonen et al. 1998, Pihlajamaki et al. 2003, Nordman et al. 2005, van Rossum et al. 2006, Ukkola \& Kesaniemi 2007, Jaakkola et al. 2009, Yeung et al. 2011, Masoudi-Kazemabad et al. 2013) without an association to increased food intake (Karvonen et al. 2006, Yeung et al. 2011).

The mechanisms whereby NPY alters energy metabolism have been elucidated in animal models. Central NPY is known to suppress the sympathetic tone, energy expenditure and brown adipose tissue (BAT) thermogenic activity, and to increase lipogenesis in white adipose tissue (WAT) (Egawa et al. 1991, Zarjevski et al. 1993, Shi et al. 2013). An important source of NPY in the periphery is the sympathetic nervous system (SNS), and NPY levels are increased upon stress (Ekblad et al. 1984). Consistently, NPY has been implicated in the stressinduced obesity, directly affecting the adipogenic and lipogenic regulation of WAT (Kuo et al. 2007, Zhang et al. 2014). In addition, chronic peripheral NPY administration induces obesity (Xie et al. 2012), and knockdown of peripheral NPY Y1- or Y2-receptors protects from dietinduced obesity by changing fuel oxidation (Zhang et al. 2010, Shi et al. 2011).

The mechanisms of NPY-induced hypercholesterolemia, IGT or earlier onset of T2D in humans are still unknown, but it can be hypothesized that hepatosteatosis plays a role in the NPY-induced metabolic and vascular diseases. Hepatosteatosis is suggested to be the hepatic manifestation of the metabolic syndrome and the actual cause of the related cardiovascular diseases ( $\mathrm{Lu}$ et al. 2013). It predicts the incidence of T2D (Vozarova et al. 2002, Lee et al. 2003), and together with diabetes increases the risk for cardiovascular events (Targher et al. 2005). In various murine models, NPY has been shown to contribute to hepatic lipogenesis, VLDLtriglyceride (TG) and VLDL-cholesterol secretion, fatty acid (FA) oxidation and increased serum cholesterol levels (Zarjevski et al. 1993, Stafford et al. 2008, Zhang et al. 2010, Bruinstroop et al. 2012, Xie et al. 2012, Zhang et al. 2014), but it is not known, whether chronic excess of NPY causes hepatosteatosis, or which hepatic mechanisms contribute to dyslipidemias and development of the metabolic syndrome.

The mouse model overexpressing NPY in central and peripheral noradrenergic neurons driven by dopaminebeta-hydroxylase $(D B H)$ gene promoter (OE-NPYDBH) presents a model of NPY-induced metabolic syndromelike phenotype without hyperphagia (Ruohonen et al. 2008, Vahatalo et al. 2014). Thus, it allows studying the mechanisms of NPY in SNS and brainstem in the pathogenesis of obesity and metabolic disturbances. Heterozygous OE-NPYDBH mice display increased fat mass and hepatic TGs, and subsequently develop hyperinsulinemia and IGT (Ruohonen et al. 2008). Homozygous OE-NPYDBH mice display a more severe obese phenotype, and the suggested mechanisms are direct effects of NPY on adipocytes, and decreased sympathetic activity to adipose tissues (Ruohonen et al. 2008, Vahatalo et al. 2014). In the current study, we aimed to elucidate the effects of noradrenergic NPY on hepatic FA, cholesterol and glucose metabolism, to define their contribution to the development of the hepatosteatosis, hypercholesterolemia and IGT, and finally, to characterize whether the changes are due to direct effects of NPY mediated via hepatic Y-receptors or due to changes in SNS activity.

\section{Materials and methods}

\section{General}

Generation of the transgenic heterozygous and homozygous OE-NPYDBH mice has been described in detail elsewhere (Ruohonen et al. 2008, Vahatalo et al. 2014). Transgenic mice were maintained on a C57BL/6N inbred background, and either heterozygote and wild-type (WT) littermates, or $1^{\text {st- }} 3^{\text {rd }}$ generation of WT and homozygous mice originating from the same heterozygous breedings were used. The mice were kept in an animal room maintained at $21 \pm 3^{\circ} \mathrm{C}$ with fixed 12-h light:12-h darkness cycle. Standard rodent chow diet (SDS, Essex, UK) and tap water were available ad libitum. At termination, 4-h-fasted mice were anesthetized with ketamine $(75 \mathrm{mg} / \mathrm{kg}$ i.p. Ketaminol, Intervet Oy, Finland) and medetomidine ( $1 \mathrm{mg} / \mathrm{kg}$ i.p. Cepetor, ScanVet Oy, Finland),

Published by Bioscientifica Ltd. 
and serum was obtained by cardiac puncture. Tissues were collected and weighed, and stored in $-70^{\circ} \mathrm{C}$. The experimental procedures were approved by the national animal care and use committee (ELLA). Animal care was in accordance with the guidelines of the International Council of Laboratory Animal Science (ICLAS).

\section{Study 1. Characterization of the phenotype of obese OE-NPYDBH mice}

Liver fat content and histology, and serum cholesterols were analyzed in 4- and 7-month-old male and female homozygous OE-NPYDBH mice. These mice were previously shown to display 1.5 -fold increase in WAT weight and a decrease in serum TG levels compared to WT controls. They develop IGT, IR, fasting hyperinsulinemia and hyperleptinemia, which are most pronounced in 7-month-old males (Vahatalo et al. 2014).

\section{Study 2. Mechanisms leading to metabolic syndrome-like phenotype in OE-NPYDBH mice}

Mechanisms of hepatosteatosis, hypercholesterolemia and IGT were first elucidated by analyzing changes in hepatic mRNA expression profile preceding any metabolic disturbances (pre-obese 2-month-old heterozygous mice, $n=4-5$ /group) that might suggest causal mechanisms. This was followed by in vivo functional assays verifying the findings in the gene expression. Homozygous male mice were used due to their more severe metabolic phenotype, except in cholesterol studies where female mice were used due to their lower level of hepatosteatosis that could induce hypercholesterolemia independent of NPY. Betaoxidation assay (supplementary information, see section on supplementary data given at the end of this article) was carried out in 2-month-old mice ( $n=6-9 /$ group) that do not yet show signs of hepatosteatosis. Cholesterol absorption and synthesis assay (supplementary information) was carried out in 6-month-old mice ( $n=5-10 /$ group), and glucose-stimulated insulinemia and hepatic glucose production in early (at 4 months) and in established obese states (at 7 months) ( $n=6-11 /$ group). Oxidative stress and inflammation as potential causes of IR were analyzed in pre-obese (at 2 months) and obese (at 5 and 7 months) states ( $n=3-10 /$ group).

\section{Glucose, pyruvate and insulin tolerance tests}

To study insulin secretion during glucose tolerance test mice were implanted with a carotid artery catheter under
$2 \%$ isoflurane anesthesia and buprenorfine analgesia $(0.1 \mathrm{mg} / \mathrm{kg}$, s.c., twice a day for 2 days, Temgesic, ScheringPlough, Brussels, Belgium). After 3-day recovery, fasted mice $(4 \mathrm{~h})$ received glucose $(1 \mathrm{~g} / \mathrm{kg}$, i.p.), and arterial blood samples $(25 \mu \mathrm{L})$ were collected using an automated blood sampling device (AccuSampler® $\mu$, VeruTech, Lund, Sweden) from awake, freely moving mice. Another set of mice were challenged for glucose $(1 \mathrm{~g} / \mathrm{kg})$ and pyruvate ( $2 \mathrm{~g} / \mathrm{kg}$, Sigma-Aldrich), which were injected (i.p.) after a 4 and 4 or $6 \mathrm{~h}$ fast, respectively. Blood glucose was measured with a glucose meter (Precision Xtra Glucose Monitoring Device, Abbott Diabetes Care, Abbot Park, IL, USA) at baseline and after the injection at the indicated time points.

\section{Study 3. Susceptibility to T2D}

The susceptibility to T2D was studied by disrupting pancreatic insulin secretion with STZ in mice with IR due to high caloric diet that induces obesity in a similar manner in OE-NPYDBH and WT mice, but is not sufficient to induce T2D in OE-NPYDBH mice (Ruohonen et al. 2012). Homozygous male OE-NPYDBH of 16-week-old and WT mice ( $n=7 /$ group) subjected to western diet $(41 \% \mathrm{kcal}$ fat, $43 \% \mathrm{kcal}$ carbohydrate, $17 \% \mathrm{kcal}$ protein, D12079B, Research Diets, New Brunswick, NJ, USA) for 3 weeks were administered a low-dose $[40 \mathrm{mg} / \mathrm{kg}$ in $7.5 \mathrm{mg} / \mathrm{ml}$ $\mathrm{Na}$-Citrate solution ( $\mathrm{pH} 4.5$ ), i.p.) of STZ (Sigma-Aldrich] after a 4-h fast on 3 consecutive days (week 0 ), followed by a single dose every 4.5 weeks to maintain hyperglycemia. Weight gain and fasting $(4 \mathrm{~h})$ tail vein blood glucose were monitored weekly and fat mass by quantitative NMR (EchoMRI-700, Echo Medical Systems, Houston, TX, USA) at weeks -3 and 9. Glucose (GTT) (1 g/kg glucose i.p. after a 4-h fast) and insulin tolerance tests (ITT) (1 IU/kg insulin i.p. after a 1-h fast) were performed at weeks 10 and 12, respectively. Tissues were collected at week 13.

\section{Study 4. Peripheral Y1R-antagonist treatment}

To study whether hepatic Y-receptors, or modulation of SNS activity, mediate the effects of noradrenergic NPY, expressions of hepatic Y- and adrenergic receptors were analyzed. The contribution of Y1-receptors was studied using a peripherally acting Y1R-antagonist, BIBO3304 trifluoroacetate (Tocris Bioscience, Bristol, UK) $(1 \mathrm{mg} / \mathrm{kg} /$ day, i.p.) (Dozio et al. 2007, Yuzuriha et al. 2007) or vehicle (DMSO, Tween ${ }^{\circledR} 80$ (Fisher Scientific, Fair Lawn, NJ, USA) and $0.9 \% \mathrm{NaCl}, 1: 1: 18$ ), which were administered to 20-week-old homozygous male OE-NPYDBH and WT

Published by Bioscientifica Ltd 
mice ( $n=10-13$ /group) over 30 days preceded by a 2 -week habituation with daily saline injections. Food intake was monitored weekly and weight gain twice a week. Body composition was measured on days $-14,0$ and 30 by quantitative NMR followed by tissue collection (after 3-h fast). As peripheral Y1-knockdown was shown to reduce respiratory exchange ratio (RER) without significantly affecting adiposity (Zhang et al. 2010), the effects of BIBO3304 vs vehicle (for 7 days preceded by 7 days habituation) were elucidated on 24-h energy expenditure (EE), RER and activity in 3-month-old WT mice $(n=4$ / group) with an indirect calorimetry (Oxylet System, Panlab, Barcelona, Spain).

\section{Biochemical assays}

Serum insulin levels were determined with Ultrasensitive Mouse Insulin ELISA Kit (Mercodia AB, Uppsala, Sweden), non-esterified fatty acids (NEFA) with the NEFA-HR(2) kit (Wako Diagnostics, Richmond, VA, USA), and total cholesterol and cholesterol fractions with a Cholesterol Quantitation Kit and with a HDL and LDL/VLDL Cholesterol Quantification Kit (Biovision) (Study 1) or Cholesterol Fluorometric Assay kit (Cayman Chemical) (Study 4). Serum and liver TGs were measured with TR0100 Serum triglyceride determination kit (Sigma-Aldrich). The hepatic TGs were analyzed from lipids purified with Folch method (Folch et al. 1957) (Study 1), or directly from the liver tissue homogenized in PBS containing 0.1\% NP-40 (Study 4).

Oxidative stress markers were analyzed in plasma, liver and urine. Total peroxyl radical trapping antioxidant potential in plasma was measured as previously described (Ahotupa et al. 1997). Hepatic diene conjugation was measured according to a previously published method (Corongiu \& Milia 1983). Glutathione reduced form (GSH) and glutathione oxidized form (GSSG) were measured by Glutathione Assay Kit (Cayman Chemical). 8-Isoprostanes were determined by STAT-8-Isoprostane EIA Kit (Cayman Chemical) and urinary creatinine by Creatinine Colorimetric Assay Kit (Cayman Chemical). Urinary 8-isoprostane was normalized relative to creatinine concentration. Serum cytokines were analyzed with MILLIPLEX MAP Mouse Cytokine/Chemokine Multiplex Assay (MCYTOMAG-70K, Millipore Corporation, Billerica, MA, USA), resistin with MILLIPLEX® Mouse Adipokine Multiplex Assay (MADKMAG-71K) and adiponectin with Mouse Adiponectin ELISA kit (EZMADP-60K, Millipore Corporation).

\section{Gene expression analyses}

RNA was extracted with Trizol Reagent (Invitrogen) or RNeasy Mini Kit (Qiagen GmbH, Hilden, Germany) with DNase treatment (RNase-Free DNase Set, Qiagen GmbH). Total RNA concentration and purity were ascertained spectrophotometrically (Lambda 20 UV/VIS Spectrometer, Perkin Elmer, Waltham, MS, USA). Microarray was performed using the Illumina MouseRef- 8 v1.1 microchip, where RNA samples were compared to 18918 genes on the chip. For the quantitative real-time PCR analysis (qPCR), RNA was converted to cDNA with High Capacity RNAto-cDNA Kit (Applied Biosystems) on a GeneAmp PCR System 9600 (Perkin Elmer). The qPCR was performed with SYBR Green method using Kapa Sybr Fast qPCR Kit (Kapa Biosystems, Woburn, MA, USA) and 7300 Real-Time PCR System (Applied Biosystems) or CFX96 Real-time PCR Detection System (Bio-Rad). The primers used in the assay are shown in Supplementary Table 1. Beta actin (Bact) was used as an endogenous control.

\section{Histology}

Liver histology was analyzed from formalin-fixed samples embedded in paraffin, sectioned $(5 \mu \mathrm{m})$ every $200 \mu \mathrm{m}$ on microscopic slides, stained with hematoxylin and eosin (H\&E) or periodic acid-Schiff (PAS), and analyzed under a standard light microscope. Hepatosteatosis was graded according to (Cabezas et al. 2012). Liver cryosections (10 $\mu \mathrm{m})$ were stained with Oil Red O (ORO) to visualize the lipid droplets. Pancreatic sections were stained with H\&E. The areas of the islets of Langerhans ( $n=69-115$ /group) were measured using the Cell ${ }^{*} \mathrm{~A}$ imaging software (Soft Imaging System, Münster, Germany). Rabbit anti-insulin (sc-9168, Santa Cruz Biotechnology, Inc.) polyclonal antibody (1:500 dilution) was used for immunohistochemical staining of the beta cells. The average area of the stained islets ( $n=5-15 /$ slide) was analyzed with ImageJ $1.48 \mathrm{v}$ (National Institute of Health, USA). The number of islets in a representative slide was calculated, and the islets were grouped according to their size.

\section{Statistical analyses}

The results were analyzed with unpaired Student's $t$-test to compare the genotype differences or two-way ANOVA and Bonferroni post hoc test to compare two genotypes and an additional challenge. Two-way ANOVA for repeated measures was used to analyze parameters over

Published by Bioscientifica Ltd. 
Table 1 Liver weights (g) of OE-NPYDBH mice in different age groups.

\begin{tabular}{|c|c|c|c|c|c|c|}
\hline \multirow[b]{2}{*}{ Age } & \multicolumn{3}{|c|}{ Female } & \multicolumn{3}{|c|}{ Male } \\
\hline & WT & OE-NPYDBH & $P$ value & WT & OE-NPYDBH & $P$ value \\
\hline 2 month & ND & ND & - & $1.43 \pm 0.02$ & $1.44 \pm 0.04$ & NS \\
\hline 4 month & $1.19 \pm 0.06$ & $1.26 \pm 0.05$ & NS & $1.29 \pm 0.11$ & $1.68 \pm 0.06$ & $<0.05$ \\
\hline 7 month & $1.05 \pm 0.02$ & $1.14 \pm 0.07$ & $<0.01$ & $1.43 \pm 0.05$ & $1.91 \pm 0.10$ & $<0.001$ \\
\hline
\end{tabular}

Liver weights were measured from 2- ( $n=6-9 /$ group), 4- ( $n=5-6 /$ group) and 7-month-old ( $n=9-11 /$ group) homozygous female and male OE-NPYDBH vs wild-type mice. Values are expressed as means \pm S.E.M. Statistics were analyzed with Student's $t$-test. ND $=$ Not diagnosed, NS $=$ non-significant.

time between genotypes. Logarithmic transformations or non-parametric Mann-Whitney test were used if data was not normally distributed (D'Agostino and Pearson omnibus normality test). Correlations were analyzed with Pearson correlation. These analyses were performed with GraphPad Prism 6.0 software (GraphPad Software, Inc.). The microarray results were analyzed by limma of the $\mathrm{R}$ statistical analysis program ( $\mathrm{R}$ language and environment for statistical computing). Pathway and cluster analysis were performed with David Bioinformation Database (http://david.abcc.ncifcrf.gov/home.jsp). The results are expressed as means \pm S.E.M. $P<0.05$ was considered statistically significant.

\section{Results}

\section{Study 1. OE-NPYDBH induces hepatosteatosis and hypercholesterolemia}

Hepatosteatosis in OE-NPYDBH mice develops with age. The livers of OE-NPYDBH male mice were heavier than those of WT controls at 4 and 7 months, but only at 7 months in females (Table 1). Hepatic lipid accumulation was detected in both sexes, and ballooning degeneration in 4- and 7-month-old male OE-NPYDBH mice (Fig. 1A and B). Hepatosteatosis was confirmed at 7 months by ORO staining and biochemical TG analysis (Fig. 1B and C). Infarcted areas (microscopic) were detected in two of four OE-NPYDBH mice, but no visible inflammation or fibrosis. Liver of obese male OE-NPYDBH mice was graded as type 3 hepatosteatosis.

Serum total cholesterol of 7-month-old male OE-NPYDBH mice was significantly increased and there was a similar trend already at 4 months in males and at 7 months in females (Table 2). LDL cholesterol was not changed, but HDL cholesterol was increased (Table 2).

\section{Study 2. Mechanisms leading to metabolic syndrome-like phenotype in OE-NPYDBH mice}

OE-NPYDBH attenuates hepatic FA oxidation To study the possible mechanisms leading to hepatosteatosis, hepatic gene expression profiles were compared between pre-obese OE-NPYDBH and WT mice by microarray analysis, which showed 27 upregulated and 12 downregulated genes in OE-NPYDBH livers (Table 3)
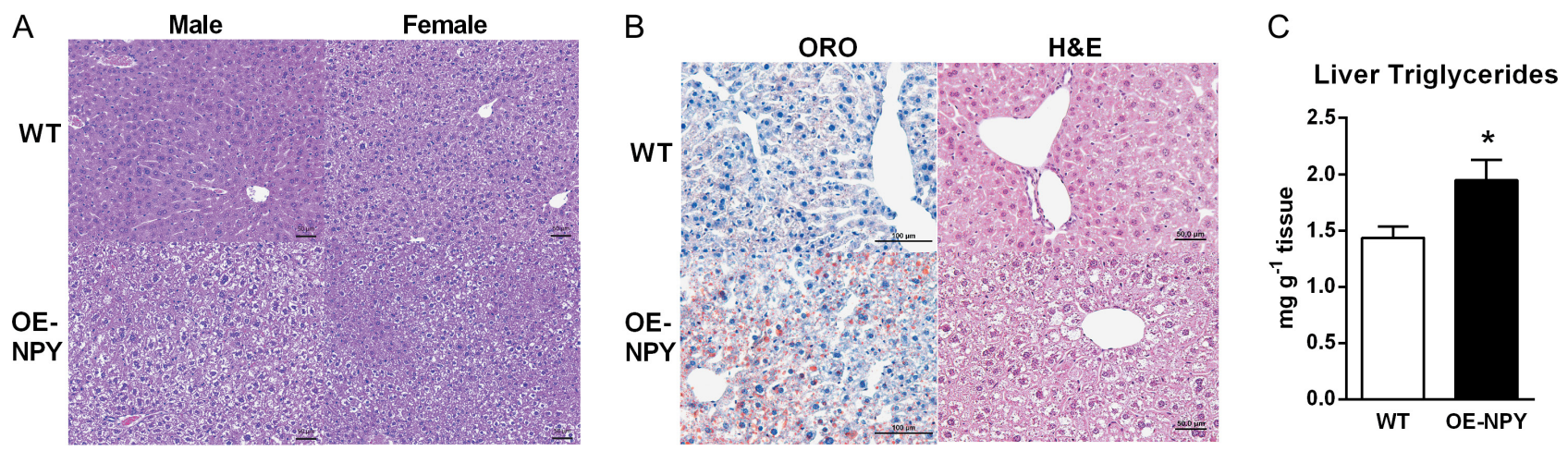

Figure 1

Liver histology and triglyceride accumulation of obese OE-NPYDBH mice. (A) Representative hematoxylin and eosin stained liver sections from 4-monthold homozygous female and male OE-NPYDBH vs wild-type mice showing ballooning degeneration and triglyceride accumulation in males (scale bar $50 \mu \mathrm{m}$ ). (B) Representative Oil red O (scale bar $100 \mu \mathrm{m}$ ) and hematoxylin and eosin (scale bar $50 \mu \mathrm{m})$ stained liver sections, and (C) liver triglyceride content of 7-month-old homozygous male OE-NPYDBH vs wild-type mice ( $n=9-10 /$ group) showing hepatosteatosis. Values are expressed as means \pm s.E.M. ${ }^{\star} P<0.05$ with Student's $t$-test. H\&E = hematoxylin and eosin staining, ORO = Oil red O staining, WT = wild-type mice, OE-NPY $=$ OE-NPYDBH mice.

http://joe.endocrinology-journals.org DOI: 10.1530/JOE-16-0223
๑) 2017 Society for Endocrinology Printed in Great Britain
Published by Bioscientifica Ltd 
Table 2 Serum cholesterol levels of obese OE-NPYDBH mice.

Female
Total Cholesterol $\left(\mu \mathrm{g} \mu \mathrm{L}^{-1}\right)$
HDL Cholesterol $\left(\mu \mathrm{g} \mu \mathrm{L}^{-1}\right)$
$\mathrm{LDL} / \mathrm{LDL}$ Cholesterol $\left(\mu \mathrm{g} \mu \mathrm{L}^{-1}\right)$
Male
Total Cholesterol $\left(\mu \mathrm{g} \mu \mathrm{L}^{-1}\right)$
HDL Cholesterol $\left(\mu \mathrm{g} \mu \mathrm{L}^{-1}\right)$
LDL/VLDL Cholesterol $\left(\mu \mathrm{g} \mu \mathrm{L}^{-1}\right)$

\begin{tabular}{c} 
WT \\
\hline $1.65 \pm 0.15$ \\
$1.17 \pm 0.08$ \\
ND \\
$1.64 \pm 0.12$ \\
$1.46 \pm 0.05$ \\
$0.37 \pm 0.06$
\end{tabular}

\section{4 months}

OE-NPYDBH

$$
\begin{gathered}
1.90 \pm 0.14 \\
1.40 \pm 0.06 \\
\text { ND }
\end{gathered}
$$

$$
\begin{aligned}
& 2.08 \pm 0.20 \\
& 1.68 \pm 0.06 \\
& 0.25 \pm 0.02
\end{aligned}
$$

Serum cholesterol levels were measured from 4- ( $n=7-11$ /group) and 7-month-old ( $n=7-10 /$ group) homozygous female and male OE-NPYDBH vs wild-type mice. Values are expressed as means \pm s.E.M.. Statistics were analyzed with Student's $t$-test. ND=Not diagnosed.

contributing in eight upregulated and five downregulated biological pathways, respectively (Table 4). Downregulated PPAR signaling and FA metabolism pathways pointed to decreased hepatic FA oxidation in OE-NPYDвH mice. In the cluster analysis, three clusters that separated the genes with similar actions were detected: retinol, arachidonic acid and linoleic acid metabolism; FA oxidation; metabolic pathways with anti-inflammatory actions (Table 5).

The most relevant genes involved in FA metabolism were selected for qPCR analysis to validate attenuated FA oxidation in OE-NPYDBH mice. Oxidative enzymes acyl-Coenzyme A oxidase 1 (Acox1) and carnitine acetyltransferase (Crat) were significantly decreased in pre-obese OE-NPYDBH mice (Fig. 2A). Decreased FA oxidation was confirmed by beta-oxidation assay (Fig. 2B). In contrast, in obese hepatosteatotic OE-NPYDBH mice an increase in Fas and a tendency in acetyl Co-A carboxylase (Acc) expression suggested increased lipogenesis, but enzymes of beta-oxidation were not significantly different (Fig. 2A).

Oxidative stress precedes hepatosteatosis in OE-NPYDBH mice In the hepatic microarray analysis, pathways involved in metabolism of xenobiotics by cytochrome P450, drug metabolism and glutathione metabolism were upregulated (Table 4), indicating that anti-inflammatory actions were recruited in the pre-obese liver. Accordingly, mRNA expression of proinflammatory cytokines, transforming growth factor beta $1(T g f b 1)$, tumor necrosis factor alfa (Tnfa) and interleukin 1 beta $(I l 1 b)$, were decreased. In the steatotic livers, proinflammatory cytokine expression was still downregulated fitting with the absence of inflammatory cells and fibrosis despite of steatosis. In contrast, 8-isoprostane, a marker of lipid peroxidation, was increased. Other markers of oxidative stress, diene conjugates, GSH or GSSG levels or GSH/GSSG ratio were not changed. Anti-inflammatory cytokine IL10 tended to be decreased $(P=0.06)$ in serum from pre-obese male OE-NPYDBH mice. In obese male mice resistin levels were increased, but IL6, IL10, adiponectin or markers of oxidative stress were not changed. Interestingly, adiponectin was increased in female OE-NPYDBH mice, which may explain their less prominent metabolic disturbances. Urinary oxidative stress markers were unchanged (Table 6).

\section{Enhanced cholesterol synthesis precedes hypercholesterolemia in OE-NPYDBH mice Obese} female OE-NPYDBH mice, representing a phenotype with hypercholesterolemia but less pronounced hepatosteatosis than the males, showed a tendency to accelerated cholesterol and bile acid synthesis in fecal analysis (Fig. 3A and B), which directly measures the whole body cholesterol metabolism. Enhanced cholesterol synthesis was confirmed by increased mRNA expression of cholesterol synthesis enzymes 3-hydroxy-3-methylglutaryl-CoA reductase (Hmgcr), farnesyl diphosphate farnesyl transferase 1 (Fdft1) and 7-dehydrocholesterol reductase (Dhcr7) in both pre-obese and obese male OE-NPYDBH mice. mRNA expression of LDL-receptor ( $L d l r)$ was not changed, but HDL transporter, scavenger receptor B1 (Srb1), was slightly decreased $(P=0.08)$ in obese mice (Fig. 3C). Cholesterol absorption was not changed (Fig. 3D and E).

\section{OE-NPYDBH mice show glucose-induced hyperinsulinemia and hepatic glycogen} accumulation Glucose-induced insulinemia was analyzed in vivo to study whether the previously observed IGT resulted from NPY-induced inhibition of insulin release or whole body IR. Insulin levels were markedly higher in OE-NPYDBH mice when glucose levels were still comparable to WT supporting IR (Fig. 4A and B). In pyruvate challenge, OE-NPYDBH mice showed

Published by Bioscientifica Ltd 
Table 3 Hepatic up- and downregulated genes in pre-obese OE-NPYDBH mice.

\begin{tabular}{|c|c|c|c|}
\hline ENTREZ ID & & Symbol & FC \\
\hline \multicolumn{4}{|c|}{ Upregulated genes } \\
\hline 11677 & aldo-keto reductase family 1 , member $\mathrm{B} 3$ (aldose reductase) & Akr1b3 & 2.45 \\
\hline 14864 & glutathione S-transferase, mu 3 & Gstm3 & 1.47 \\
\hline 67106 & zinc finger and BTB domain containing 8 opposite strand & Zbtb8os & 1.44 \\
\hline 232174 & cytochrome P450, family 26, subfamily b, polypeptide 1 & Cyp26b1 & 2.01 \\
\hline 13095 & cytochrome P450, family 2, subfamily c, polypeptide 29 & Cyp2c29 & 1.65 \\
\hline 17448 & malate dehydrogenase 2, NAD (mitochondrial) & Mdh2 & 1.64 \\
\hline 14629 & glutamate-cysteine ligase, catalytic subunit & Gclc & 1.45 \\
\hline 18534 & phosphoenolpyruvate carboxykinase 1, cytosolic & Pck1 & 1.63 \\
\hline 20893 & basic helix-loop-helix domain containing, class B2 & Bhlhb2 & 1.72 \\
\hline 105387 & aldo-keto reductase family 1 , member C14 & Akr1c14 & 1.53 \\
\hline 67758 & arylacetamide deacetylase (esterase) & Aadac & 1.70 \\
\hline 68041 & Mid1 interacting protein 1 (gastrulation specific G12-like (zebrafish)) & Mid1ip1 & 1.48 \\
\hline 66270 & RIKEN CDNA $1810015 C 04$ gene & 1810015C04Rik & 1.50 \\
\hline 107141 & cytochrome P450, family 2 , subfamily c, polypeptide 50 & Cyp2c50 & 1.44 \\
\hline 50790 & acyl-CoA synthetase long-chain family member 4 & Acs/4 & 1.49 \\
\hline 14104 & fatty acid synthase & Fasn & 1.41 \\
\hline 12452 & cyclin G2 & Cong2 & 1.52 \\
\hline 14857 & glutathione S-transferase, alpha 1 (Ya) & Gsta1 & 1.68 \\
\hline 14858 & glutathione S-transferase, alpha 2 (Yc2) & Gsta2 & 1.48 \\
\hline 14960 & histocompatibility 2, class II antigen A, alpha & $H 2-A a$ & 1.63 \\
\hline 66046 & NADH dehydrogenase (ubiquinone) 1 beta subcomplex, 5 & Ndufb5 & 1.42 \\
\hline 72082 & cytochrome P450, family 2, subfamily c, polypeptide 55 & Cyp2c55 & 1.46 \\
\hline 27400 & hydroxysteroid (17-beta) dehydrogenase 6 & Hsd17b6 & 1.74 \\
\hline 16648 & karyopherin (importin) alpha 3 & Kpna3 & 1.42 \\
\hline 67603 & dual specificity phosphatase 6 & Dusp6 & 1.62 \\
\hline 12116 & betaine-homocysteine methyltransferase & Bhmt & 1.47 \\
\hline 14828 & heat shock protein 5 & Hspa5 & 1.50 \\
\hline \multicolumn{4}{|c|}{ Downregulated genes } \\
\hline 11430 & acyl-Coenzyme A oxidase 1, palmitoyl & Acox 1 & -1.49 \\
\hline 12908 & carnitine acetyltransferase & Crat & -1.43 \\
\hline 13119 & cytochrome P450, family 4, subfamily a, polypeptide 14 & Сур4а14 & -1.59 \\
\hline 74147 & $\begin{array}{l}\text { enoyl-Coenzyme A, hydratase/3-hydroxyacyl Coenzyme A } \\
\text { dehydrogenase }\end{array}$ & Ehhadh & -1.48 \\
\hline 11520 & adipose differentiation related protein & Adfp & -1.42 \\
\hline 17068 & lymphocyte antigen 6 complex, locus D & Ly6d & -1.45 \\
\hline 13117 & cytochrome P450, family 4 , subfamily a, polypeptide 10 & Сур4а 10 & -1.43 \\
\hline 16427 & inter alpha-trypsin inhibitor, heavy chain 4 & Itih4 & -1.11 \\
\hline 16803 & lipopolysaccharide binding protein & $L b p$ & -1.62 \\
\hline 66058 & transmembrane protein $176 \mathrm{~A}$ & Tmem176a & -1.44 \\
\hline 16819 & lipocalin 2 & Len2 & -4.29 \\
\hline 15439 & haptoglobin & $H p$ & -1.47 \\
\hline
\end{tabular}

Up- and downregulated genes were measured in the livers of 2-month-old heterozygous OE-NPYDBH vs wild-type mice ( $n=4 / g$ roup) by limma of the R statistical analysis program. Genes were considered significantly up- or downregulated when $P<0.05$. FC $=$ fold change.

decreased gluconeogenesis when statistically significant difference in GTT was not yet revealed, but when IGT was established, there was no difference in PTT or expression of gluconeogenic enzymes (Fig. 4C and E). The average size of islets of Langerhans in obese OE-NPYDBH mice was enlarged (WT 0.013 $\pm 0.001 \mathrm{~mm}^{2}$; OE-NPYDBH $\left.0.020 \pm 0.002 \mathrm{~mm}^{2} ; \quad P<0.001\right)$ supporting previously detected hyperinsulinemia. Furthermore, obese OE-NPYDBH mice displayed hepatic glycogen accumulation (Fig. 4F) preceded by increased expression of both glycogen synthase (Gys2) and phosphorylase
$(P y g l)$ (Fig. 4E), which suggest acceleration of glycogen cycling.

\section{Study 3. OE-NPYDBH increases susceptibility to STZ-induced diabetes}

Susceptibility to T2D was studied by subjecting 16-weekold OE-NPYDвн and WT mice to high caloric diet and low doses of STZ. Both genotypes gained weight and fat mass similarly (Fig. 5A and B). Fasting (4h) glucose was significantly increased in OE-NPYDBH mice and showed 
Table 4 Pathway analysis of hepatic up- and downregulated genes in pre-obese OE-NPYDBH mice.

\begin{tabular}{|c|c|c|c|}
\hline Pathway name & Number of genes & $P$ value & FRD \\
\hline \multicolumn{4}{|l|}{ Upregulated pathways } \\
\hline $\begin{array}{l}\text { Metabolism of } \\
\text { xenobiotics by } \\
\text { cytochrome P450 }\end{array}$ & 6 & $<0.001$ & $<0.001$ \\
\hline Drug metabolism & 6 & $<0.001$ & $<0.001$ \\
\hline Glutathione metabolism & 4 & $<0.001$ & 0.56 \\
\hline Retinol metabolism & 4 & 0.001 & 1.23 \\
\hline Pyruvate metabolism & 3 & 0.007 & 6.99 \\
\hline Linoleic acid metabolism & 3 & 0.009 & 8.67 \\
\hline $\begin{array}{l}\text { Arachidonic acid } \\
\text { metabolism }\end{array}$ & 3 & 0.030 & 24.42 \\
\hline Citrate cycle (TCA cycle) & 2 & 0.098 & 61.06 \\
\hline \multicolumn{4}{|l|}{ Downregulated pathways } \\
\hline Fatty acid metabolism & 4 & $<0.001$ & 0.00 \\
\hline PPAR signaling pathway & 4 & $<0.001$ & 0.00 \\
\hline Retinol metabolism & 2 & 0.047 & 30.06 \\
\hline $\begin{array}{l}\text { Arachidonic acid } \\
\text { metabolism }\end{array}$ & 2 & 0.057 & 35.40 \\
\hline $\begin{array}{l}\text { Vascular smooth muscle } \\
\text { contraction }\end{array}$ & 2 & 0.081 & 46.94 \\
\hline
\end{tabular}

Pathway analysis was based on the microarray analysis in the livers of 2-month-old heterozygous OE-NPYDBH vs wild-type mice ( $n=4 /$ group). The analysis was performed with DAVID Bioinformatics Resources. FDR $=$ False discovery rate (\%), an adjusted $P$ value, which estimates the probability of significant $P$ value $(<0.05)$ being false.

diabetic levels (over $13.8 \mathrm{mmol} \mathrm{L}^{-1}$ in mice) after 4 weeks of the first STZ administration (Fig. 5C). Glucose clearance in GTT was decreased in OE-NPYDBH when compared to

Table 5 Cluster analysis of hepatic up- and downregulated genes in pre-obese OE-NPYDBH mice.

\begin{tabular}{|c|c|c|c|c|}
\hline & Score & $\begin{array}{l}\text { Number } \\
\text { of genes }\end{array}$ & $P$ value & FDR \\
\hline Cluster 1 & 3.97 & & & \\
\hline Retinol metabolism & & 6 & $<0.001$ & 0.01 \\
\hline $\begin{array}{l}\text { Arachidonic acid } \\
\text { metabolism }\end{array}$ & & 5 & $<0.001$ & 0.34 \\
\hline Linoleic acid metabolism & & 3 & 0.016 & 14.2 \\
\hline Cluster 2 & 3.34 & & & \\
\hline PPAR signaling pathway & & 6 & $<0.001$ & 0.02 \\
\hline Fatty acid metabolism & & 5 & $<0.001$ & 0.03 \\
\hline Cluster 3 & 2.85 & & & \\
\hline $\begin{array}{l}\text { Metabolism of xenobiotics } \\
\text { by cytochrome P450 }\end{array}$ & & 6 & $<0.001$ & 0.00 \\
\hline Drug metabolism & & 6 & $<0.001$ & 0.01 \\
\hline Glutathione metabolism & & 4 & 0.001 & 1.2 \\
\hline
\end{tabular}

Cluster analysis was based on the microarray analysis in the livers of 2-month-old heterozygous OE-NPYDBH vs wild-type mice ( $n=4 /$ group). The analysis was performed with DAVID Bioinformatics Resources. Biological pathways are clustered into homogenous clusters which differ from other clusters: the higher score of the cluster, the higher homogeneity within the cluster. FDR =False discovery rate (\%), adjusted $P$ value, which estimates the probability of significant $P$ value $(<0.05)$ being false.
WT mice (Fig. 5D) but diet-induced IR was evident in both genotypes (Fig. 5E). Fasting serum insulin levels were equally low (Fig. 5F), and there was no difference between the genotypes in the amount, size or intensity of insulin antibody stained areas in pancreas (Fig. 5G and H). Livers of OE-NPYDBH mice were non-significantly enlarged (WT $1.59 \pm 0.08 \mathrm{~g} ; \mathrm{OE}-\mathrm{NPY}$ DBH $1.90 \pm 0.14 \mathrm{~g} ; P=0.08$ ) and relative liver weights correlated positively with mean fasting blood glucose values $\left(P<0.001, \mathrm{r}^{2}=0.62\right)$. Both genotypes showed severe hepatosteatosis, but not steatohepatitis (data not shown).

\section{Study 4. Hepatic beta1-adrenoceptors but not Y-receptors contribute to the phenotype of OE-NPYDBH mice}

Contribution of increased sympathetic NPY and modulated catecholamine release on the phenotype of OE-NPYDBH mice was first evaluated by analyzing hepatic mRNA expression of Y1 (Y1r), Y2 (Y2r), beta1- (Adrb1) and beta2-adrenergic (Adrb2) receptors. $Y 1 r$ and $A d r b 2$ expressions were similar between genotypes, but Adrb1 expression was decreased in OE-NPYDBH mice (Fig. 6A). $Y 2 r$ was undetected.

Y1-receptor mediated actions of NPY were further elucidated with chronic peripheral Y1R-antagonist treatment. Y1R-antagonist did not prevent the phenotype, i.e. obesity, hepatosteatosis, IR, hyperinsulinemia, hypercholesterolemia or oxidative stress, in OE-NPYDBH mice, nor had an effect on food intake (Fig. 6B-I and Table 7). However, in WT mice it decreased serum TGs and increased liver cholesterol (Fig. 6E and H). EE (relative to lean mass), RER and total activity were similar in both treatment groups after 1- (data not shown) and 7-daytreatment (Fig. 6J, K and L).

\section{Discussion}

We have previously shown that homozygous OE-NPYDBH mice develop obesity, IGT and IR (Vahatalo et al. 2014). In this study, we show that they also develop hepatosteatosis and hypercholesterolemia, and that this phenotype renders them susceptible to T2D. We previously published that the mechanism of obesity in OE-NPYDBH mice lies mostly in decreased sympathetic signaling in adipose tissues (Vahatalo et al. 2014). The current work shows that changes in hepatic lipid, glucose and cholesterol metabolism, and oxidative stress precede obesity, and suggests that decreased sympathetic signaling also in the

Published by Bioscientifica Ltd 
A

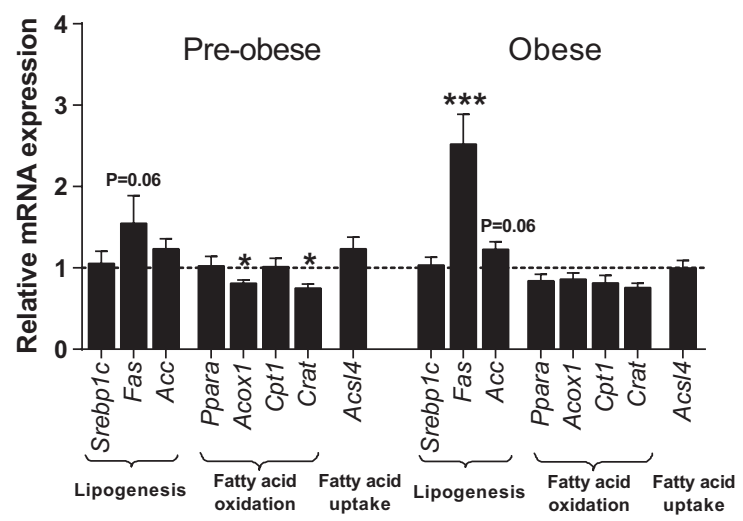

B

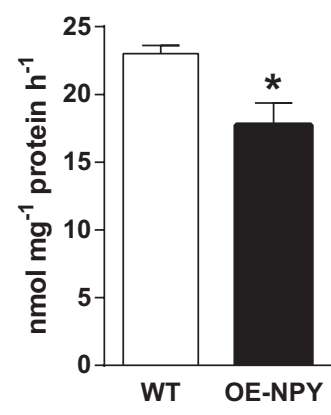

Figure 2

Hepatic fatty acid metabolism in OE-NPYDBH mice. (A) mRNA expression of selected genes involved in fatty acid metabolism in 2-month-old heterozygous (pre-obese) ( $n=5 /$ group) and 7-month-old homozygous (obese) ( $n=10 /$ group) OE-NPYDBH mice relative to wild-type mice. Beta actin was used as endogenous control. (B) Total palmitate oxidation in the livers of 2-month-old homozygous OE-NPYDBH vs wild-type mice ( $n=6-9$ /group). Values are expressed as means \pm S.E.M. ${ }^{*} P<0.05$ and $* * * P<0.001$ with Student's $t$-test. Srebp1c $=$ Sterol regulatory element binding transcription factor 1, Fas= fatty acid synthase, $A c c=$ acetyl-CoA carboxylase, Ppara $=$ peroxisome proliferator-activated receptor alpha, $A c 0 x 1=$ acyl-Coenzyme $A$ oxidase 1, Cpt1 = carnitine palmitoyltransferase 1, Crat=carnitine acetyltransferase, $A c s / 4=$ acyl-CoA synthetase long-chain family member 4 , $\mathrm{WT}=$ wild-type mice, $\mathrm{OE}-\mathrm{NPY}=\mathrm{OE}-\mathrm{NPYDBH}$ mice. liver importantly contributes to the development of the metabolic disturbances in OE-NPYDBH mice.

The mechanisms of hepatosteatosis in OE-NPYDBH mice were studied in pre-obese state in order to elucidate the causal factors and to avoid the TG accumulation-induced disturbances on FA metabolism, (i.e. increased lipogenesis and FA oxidation). The results show that decreased FA oxidation precedes hepatosteatosis OE-NPYDBH mice. Instead, lipogenesis is significantly increased in steatotic livers, and is likely a consequence of hepatosteatosis and hyperinsulinemia that are known to activate lipogenic enzymes and lipogenesis (Assimacopoulos-Jeannet et al. 1995, Donnelly et al. 2005, Matsuzawa-Nagata et al. 2008). Hepatic FA uptake or VLDL secretion were not measured,

Table 6 Oxidative stress markers and cytokines in OE-NPYDBH mice.

\begin{tabular}{|c|c|c|c|c|c|c|}
\hline & \multicolumn{3}{|c|}{ Pre-obese } & \multicolumn{3}{|c|}{ Obese } \\
\hline & WT & OE-NPYDBH & $P$ value & WT & OE-NPYDBH & $P$ value \\
\hline \multicolumn{7}{|l|}{ Blood } \\
\hline IL6 (pg mL-1) & $10.83 \pm 3.74$ & $10.60 \pm 7.38$ & 0.87 & $3.25 \pm 0.01$ & $8.67 \pm 3.19$ & 0.78 \\
\hline IL10 (pg mL-1I) & $17.75 \pm 5.14$ & $8.80 \pm 3.35$ & 0.06 & $20.63 \pm 9.29$ & $23.80 \pm 6.13$ & 0.58 \\
\hline TRAP & ND & ND & - & $216.40 \pm 14.32$ & $231.30 \pm 7.97$ & 0.39 \\
\hline 8-Isoprostane (pg mL-1I) & ND & ND & - & $326.3 \pm 16.60$ & $347.3 \pm 13.80$ & 0.35 \\
\hline \multicolumn{7}{|l|}{ Urine } \\
\hline 8-Isoprostane/Creatinine & ND & ND & - & $0.047 \pm 0.00$ & $0.042 \pm 0.01$ & 0.33 \\
\hline \multicolumn{7}{|l|}{ Liver } \\
\hline Dienconjugation (pmol mg-1) & ND & ND & - & $651.70 \pm 16.20$ & $672.10 \pm 7.90$ & 0.51 \\
\hline 8-Isoprostane (pg mg-1) & ND & ND & - & $70.40 \pm 3.10$ & $83.40 \pm 4.50$ & $<0.05$ \\
\hline $\mathrm{GSH}\left(\mathrm{pg} \mathrm{mg} \mathrm{m}^{-1}\right)$ & ND & ND & - & $30.30 \pm 1.60$ & $31.70 \pm 0.70$ & 0.45 \\
\hline GSSG (pg mg-1) & ND & ND & - & $7.9 \pm 0.5$ & $8.00 \pm 0.40$ & 0.87 \\
\hline GSH/GSSG (pg mg-1) & ND & ND & - & $0.26 \pm 0.00$ & $0.26 \pm 0.01$ & 0.55 \\
\hline \multicolumn{7}{|l|}{ mRNA expression } \\
\hline$/ / 1 b$ & $0.92 \pm 0.33$ & $0.70 \pm 0.11$ & 0.28 & $0.97 \pm 0.18$ & $0.43 \pm 0.05$ & $<0.01$ \\
\hline Tnfa & $1.24 \pm 0.40$ & $0.55 \pm 0.12$ & 0.06 & $1.14 \pm 0.19$ & $0.48 \pm 0.13$ & $<0.01$ \\
\hline Tgfb1 & $1.01 \pm 0.07$ & $\begin{array}{l}0.77 \pm 0.10 \\
\text { Female }\end{array}$ & $<0.05$ & $1.04 \pm 0.09$ & $\begin{array}{l}0.56 \pm 0.07 \\
\text { Male }\end{array}$ & $<0.001$ \\
\hline Blood & WT & OE-NPYDBH & $P$ value & WT & OE-NPYDBH & $P$ value \\
\hline Resistin (ng mL-1l) & $3.35 \pm 0.37$ & $3.35 \pm 0.30$ & 0.99 & $1.98 \pm 0.20$ & $3.04 \pm 0.39$ & $<0.05$ \\
\hline Adiponectin (pg mL-1| ) & $14.70 \pm 0.85$ & $18.50 \pm 0.82$ & $<0.01$ & $9.70 \pm 0.58$ & $10.47 \pm 0.61$ & 0.40 \\
\hline \multicolumn{7}{|c|}{ 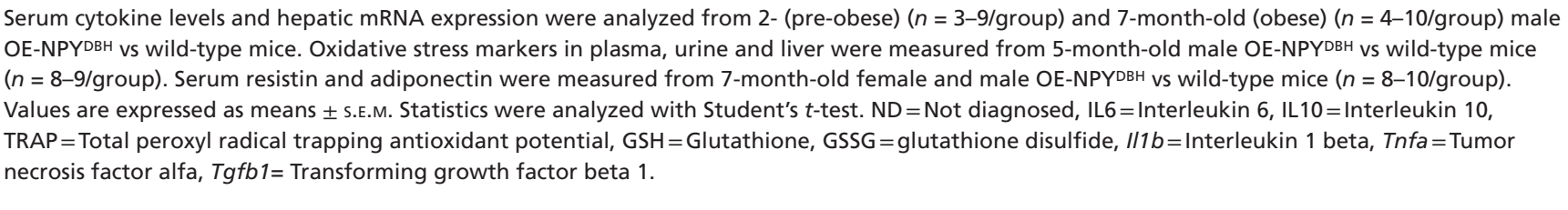 } \\
\hline $\begin{array}{l}\text { http://joe.endocrinology-journals.org } \\
\text { DOI: } 10.1530 / J O E-16-0223\end{array}$ & $\begin{array}{r}\text { () } 2017 \text { Socie } \\
\text { Pr }\end{array}$ & $\begin{array}{l}\text { or Endocrinology } \\
\text { d in Great Britain }\end{array}$ & b & Ltd. & & \\
\hline
\end{tabular}


A

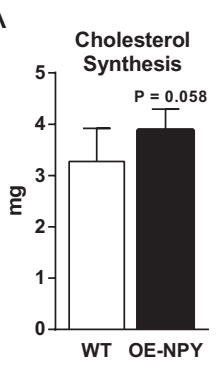

D

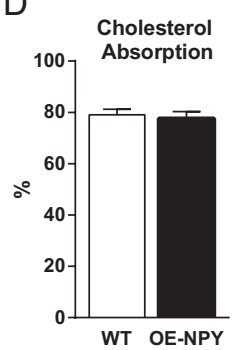

B

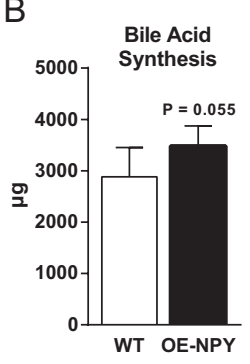

C

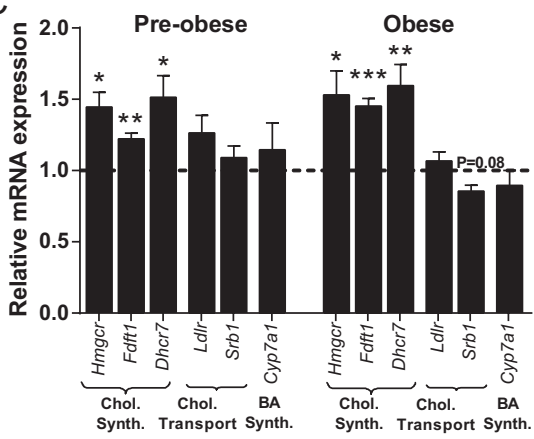

E

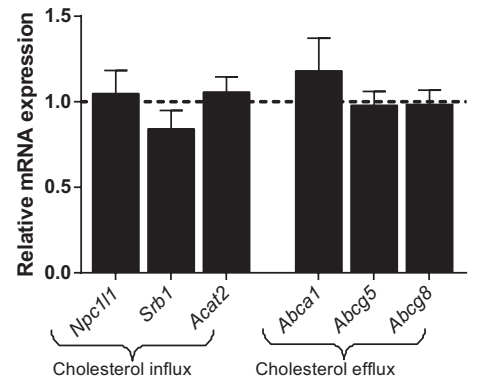

but suppressed lipolysis, decreased serum TG and nonesterified FA levels and simultaneous accumulation of TGs into the liver and WAT argue against increased flux of lipids from WAT to the liver (Vahatalo et al. 2014).

Hepatic TG accumulation in obese OE-NPYDBH mice develops into type 3 hepatosteatosis characterized by lipid droplets and ballooning degeneration without inflammation and fibrosis. However, markers of inflammation were detected both in pre-obese and obese states, which together with hepatosteatosis may contribute to the development of IR and T2D in OE-NPYDBH mice. The upregulated anti-inflammatory pathways in pre-obese livers, usually considered a secondary response to oxidative stress, may be an early sign of disruptions in hepatic FA metabolism. 8-Isoprostane, a marker for oxidative stress (reviewed by (Roberts \& Morrow 2000)), was elevated in steatotic livers. Decreased levels of anti-inflammatory cytokine IL10 in pre-obese state may also promote metabolic disturbances, as IL10 has been shown to protect from hepatosteatosis and IR (Dagdeviren et al. 2016, Paredes-Turrubiarte et al. 2016). Furthermore, although inflammatory cells were not present in expanding WAT (Vahatalo et al. 2014), we detected elevated levels of resistin, whose production has previously been shown to be stimulated by NPY in
WAT (Yuzuriha et al. 2003, Kuo et al. 2007). Resistin can independently induce IGT and IR (Steppan et al. 2001, Rajala et al. 2003), and it associates with T2D, obesity and inflammation (McTernan et al. 2003, Shetty et al. 2004, Fu et al. 2006). Interestingly, we also detected decreased expression of cytokines (Il1b, Tnfa and Tgfb1), usually associated with the development of steatohepatitis. Decreased FA oxidation, (i.e. decreased production of ROS) or cytokine-independent oxidative stress may explain this discrepancy to our other results. Presumably NPY has anti-inflammatory effects (Wheway et al. 2005, Ferreira et al. 2010), but it has also been shown to be upregulated in human hepatosteatosis and to be involved in the development of fibrosis (Sigala et al. 2013, Zhu et al. 2015). Together with our results they suggest that NPY has a dual role in inflammation.

NPY variant (rs16139) is associated with hypercholesterolemia and atherosclerosis (Karvonen et al. 1998, 2001), and in consistence, obese OE-NPYDBH mice showed elevated serum total and HDL cholesterol together with a tendency of decreased HDL-receptor, Srb1, expression, which all associate with T2D or atherosclerosis in mice (Nishina et al. 1994, Kozarsky et al. 2000). VLDL/ LDL fraction was not changed, which may be influenced by decreased serum TGs, the main component of VLDL, 
A

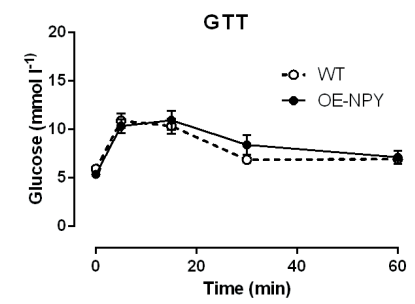

C

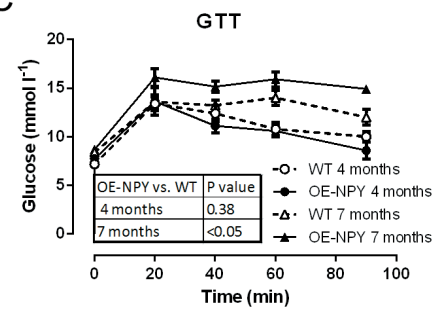

B

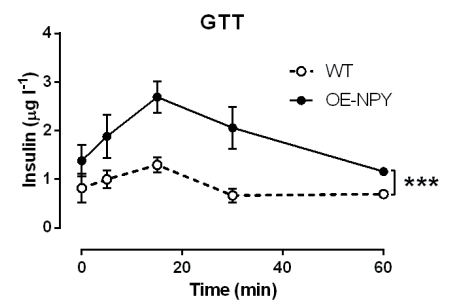

D

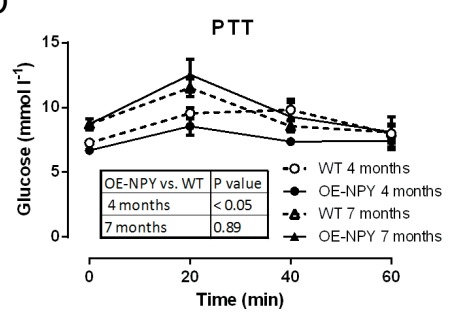

E

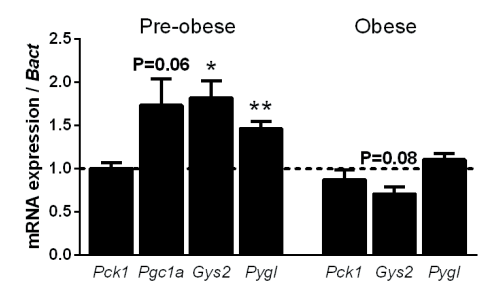

F

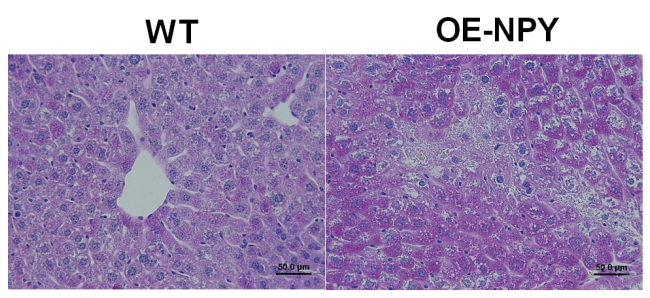

Figure 4

Glucose metabolism in OE-NPYDBH mice. (A) Glucose tolerance test and (B) glucose-induced hyperinsulinemia in 4-month-old homozygous OE-NPYDBH vs wild-type mice ( $n=7 /$ group). (C) Glucose (D) and pyruvate tolerance tests of 4-month-old and 7-month-old homozygous OE-NPYDBH vs wild-type mice ( $n=6-11 /$ group). (E) mRNA expression of selected genes involved in glucose metabolism in 2-month-old heterozygous (pre-obese) ( $n=5 /$ group) and 7-month-old homozygous (obese) ( $n=10 /$ group) OE-NPYDBH mice relative to wild-type mice. Beta actin was used as endogenous control. (F) Representative periodic acid-Schiff stained liver slides showing glycogen accumulation into the hepatocytes in 7-month-old OE-NPYDBH vs wild-type mice (scale bar $50 \mu \mathrm{m}$ ). Values are expressed as means \pm S.E.M. ${ }^{*} P<0.05, * * P<0.01$ and $* * * P<0.001$ with two-way ANOVA of repeated measures (A-D) or Student's $t$-test $(\mathrm{E}) . \mathrm{GTT}=$ glucose tolerance test, $\mathrm{PTT}=$ pyruvate tolerance test, $P c k 1=$ phosphoenolpyruvate carboxykinase $1, P g c 1 \mathrm{a}=$ peroxisome proliferative activated receptor, gamma, coactivator 1 alpha, Gys2=Glycogen synthase 2, Pygl=liver glycogen phosphorylase, WT=wild-type mice, OE-NPY =OE-NPYDBH mice.

previously observed in these mice (Vahatalo et al. 2014). The mechanism of hypercholesterolemia in OE-NPYDBH mice is elevated cholesterol synthesis without a change in cholesterol absorption. As this is detected already in preobese state, thus without agitation of hepatosteatosis or the metabolic syndrome (Gylling et al. 2007, Simonen et al. 2011), we suggest that the hepatic cholesterol synthesis is elevated by noradrenergic NPY and explains the hypercholesterolemia of obese OE-NPYDBH mice.

The mechanism of IGT, previously detected in OE-NPYDBH mice (Vahatalo et al. 2014), was scrutinized in states of early and in established obesity. In the early stage, OE-NPYDBH mice seem to compensate elevated blood glucose levels effectively by increasing insulinemia and by restoring excess energy to glycogen and TGs by the liver. This was demonstrated by almost absent pyruvate-induced increase in glucose levels, and by increased glycogen metabolism known to associate with T2D (Hundal et al. 2000). Based on previous findings (Cho \& Kim 2004, Machida et al. 2014), NPY unlikely increases pancreatic insulin secretion directly, and glucose-induced hyperinsulinemia in OE-NPYDBH mice is rather secondary to systemic IR. With aging, IGT, IR and fasting hyperinsulinemia (Vahatalo et al. 2014) with enlarged pancreatic islets, and hepatic glycogen accumulation, as shown here, become evident. To test whether this phenotype similar to carriers of rs16139 (Ukkola \& Kesaniemi 2007, Jaakkola et al. 2009, Nordman et al. 2005) renders OE-NPYDBH mice susceptible to T2D, the mice were exposed to low-dose STZ to interfere with pancreatic beta cells less than in the traditional T1D STZ-model, and high caloric diet to induce IR (Gilbert et al. 2011). Only OE-NPYDBH mice reached diabetic fasting blood glucose levels, thus showing higher susceptibility to T2D. They also showed augmented response in GTT, despite comparably low fasting insulin levels and severe IR as WT mice. However, it is presumable that glucose-stimulated insulin release was impaired in OE-NPYDBH mice, and likely with a higher insulin dose or a more sensitive method to assess insulin sensitivity, more severe IR would have been detected in OE-NPYDBH mice.

Previously, the effects of NPY on hepatic metabolism have mostly been attributed to central, hypothalamic effects (Zarjevski et al. 1993, Stafford et al. 2008), but also peripheral effects are possible (Zhang et al. 2010, Xie et al. 2012). In order to elucidate whether the observed changes in OE-NPYDBH mice are due to NPY's direct effect in the liver, or altered SNS activity, hepatic NPY and adrenergic receptor expressions were analyzed. As presence of hepatic

Published by Bioscientifica Ltd 
A

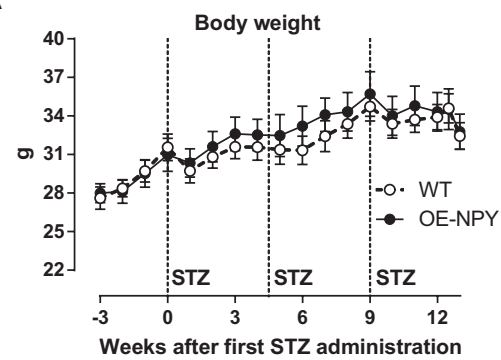

D

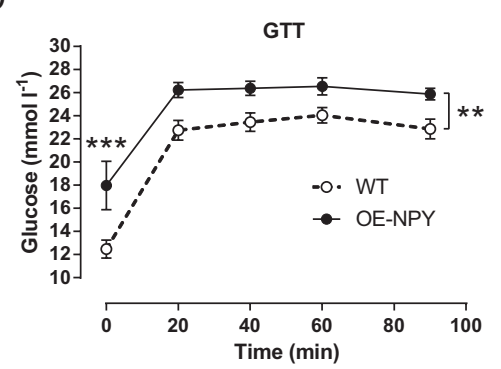

B

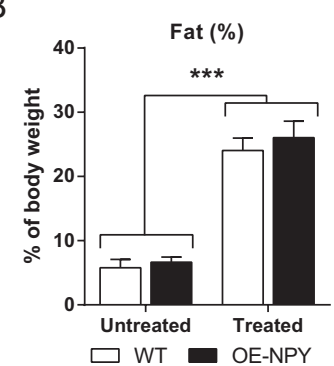

C

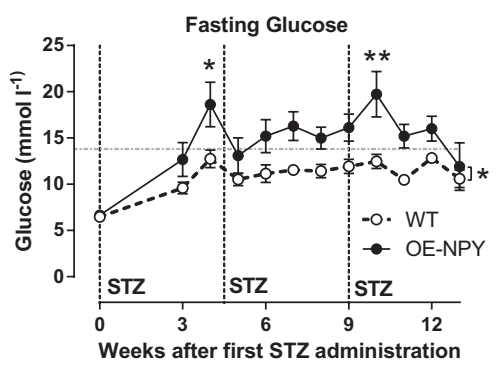

F

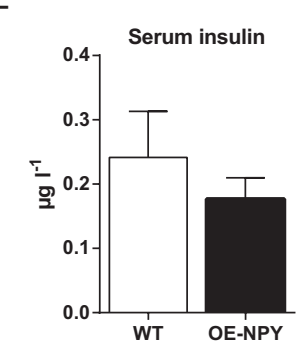

G

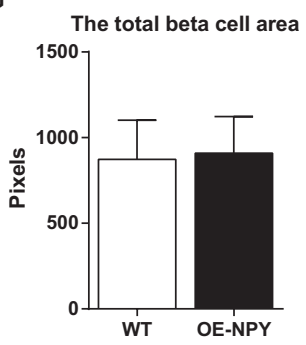

E

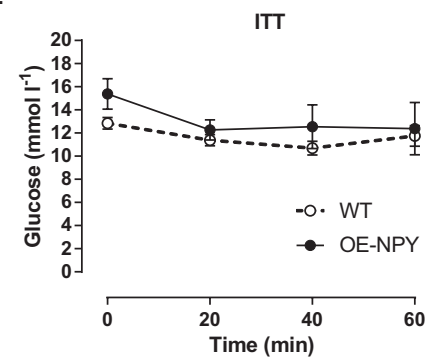

$\mathrm{H}$

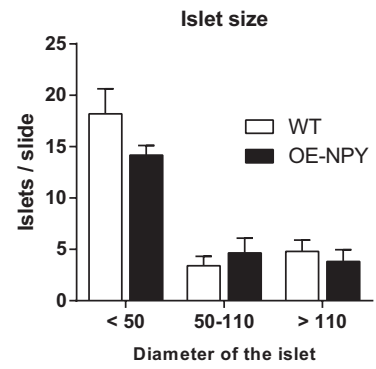

Figure $\mathbf{5}$

Type 2 diabetes model in OE-NPYDBH mice. (A) Weight gain, (B) whole body fat mass \%, (C) fasting blood glucose, (D) glucose and (E) insulin tolerance tests, (F) fasting serum insulin levels, (G) quantitated pancreatic insulin intensity, and (H) the amount and size of beta cells in homozygous OE-NPYDBH vs wild-type mice ( $n=7 /$ group) subjected to high caloric diet from age of 13 weeks and low-dose streptozotocin from age of 16 weeks (Week 0 ) onwards. Values are expressed as means \pm S.E.M. ${ }^{*} P<0.05, * * P<0.01$ and $* * * P<0.001$ with two-way ANOVA and Bonferroni post hoc test (B) or two-way ANOVA of repeated measures (C-D). Gray dashed line = glucose $13.8 \mathrm{mmol} \mathrm{L-1}$, the limit for diabetes in mice, STZ=streptozotocin, GTT=glucose tolerance test, $\mathrm{ITT}=$ Insulin tolerance test, WT = wild-type mice, OE-NPY $=\mathrm{OE}-\mathrm{NPYDBH}$ mice.

Y1-receptors (but not Y2-receptors) was detected, and peripheral Y1-receptor knockdown has previously shown beneficial effects on hepatic FA metabolism (Zhang et al. 2010), their contribution was studied by chronic treatment with a peripheral Y1R-antagonist, BIBO3044. Opposite to our hypothesis, Y1R-antagonist was unable to prevent the metabolic phenotype of OE-NPYDBH mice. Thus, in the model of excess noradrenergic NPY, peripheral Y1-receptors seem to play a minor role in the phenotype. Furthermore, in WT mice, peripheral Y1-receptor antagonism did not produce similar beneficial effects, e.g. increased FA oxidation, as Y1-receptor knockdown. In contrast, reduced serum TGs and increased hepatic cholesterol point to metabolic disturbances similar to what is seen in OE-NPYDBH mice and high fat diet-fed mice (Gao et al. 2010).

Attenuated SNS activity in adipose tissue was previously shown to contribute to obesity in OE-NPYDBH mice, and therefore similar actions in the liver were considered as another probable mechanism. A significant decrease in Adrb1 expression both in heterozygous and homozygous OE-NPYDBH mice was detected, although they display opposite effects of NPY overexpression on catecholamine levels with heterozygous showing increased and homozygous mice decreased sympathetic tone (Ruohonen et al. 2008, Vahatalo et al. 2014). Despite this discrepancy, the metabolic phenotype is similar, albeit more pronounced in the homozygous model. 


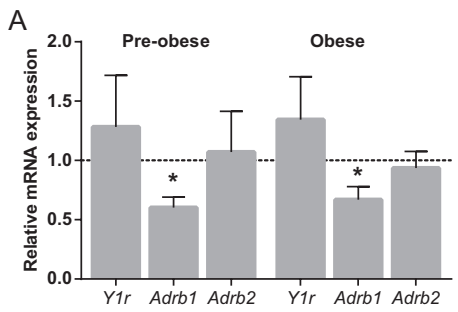

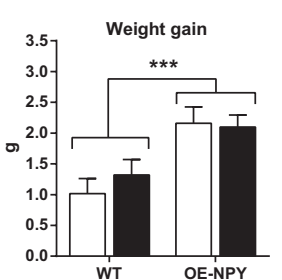

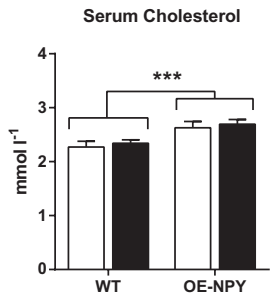

J

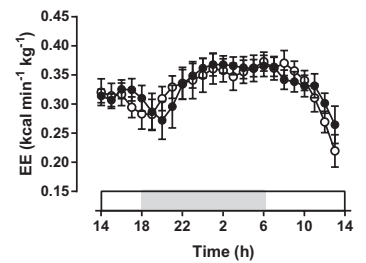

C

G
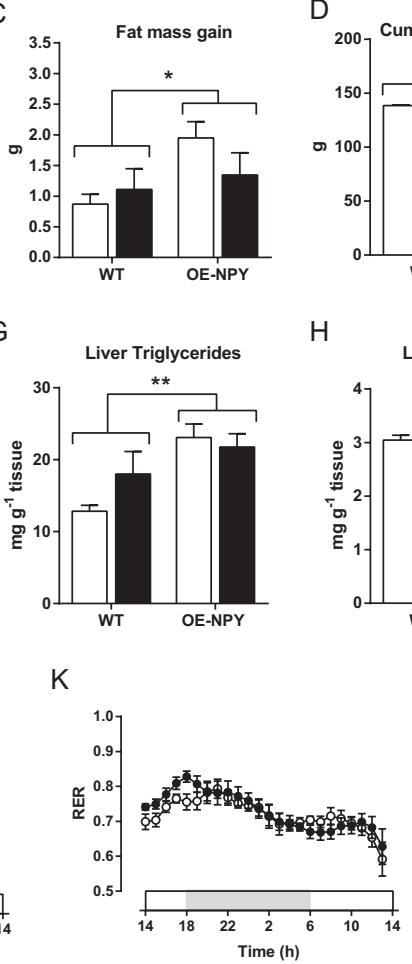

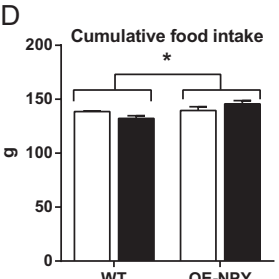

E

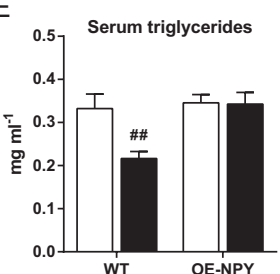

$\mathrm{H}$
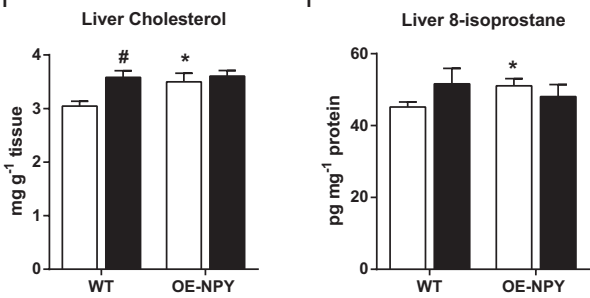

L

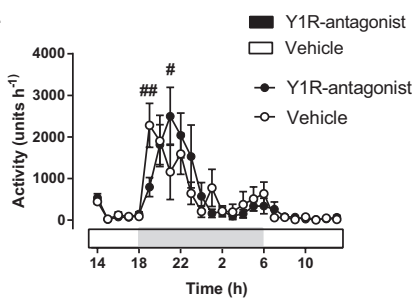

\section{Figure 6}

Roles of NPY and adrenergic receptors in OE-NPYDBH mice. (A) mRNA expression of liver NPY- and adrenergic receptors in 2-month-old heterozygous (pre-obese) ( $n=4-5 / g r o u p)$ and 7-month-old homozygous (obese) ( $n=6-7 / g r o u p)$ OE-NPYDBH mice relative to wild-type mice. Beta actin was used as endogenous control. (B) Weight gain, (C) fat mass gain, (D) cumulative food intake, (E-F) serum lipids, (G-H) liver lipids and I) liver 8-isoprostane in OE-NPYDBH vs wild-type mice ( $n=10-13 /$ group) treated with Y1R-antagonist BIBO3044 or vehicle for 4 weeks. (J) Energy expenditure, (K) respiratory exchange ratio and (L) physical activity of wild-type mice ( $n=4 /$ group) treated with $Y 1$ R-antagonist or vehicle for 1 week. Values are expressed as means \pm S.E.M. ${ }^{*} P<0.05, * * P<0.01$ and $* * * P<0.001$ difference between genotypes with Student's $t$-test (A, H and I) or with two-way ANOVA and Bonferroni post hoc test (B-D and $\mathrm{F}-\mathrm{G}$ ). ${ }^{\#} P<0.05$ and ${ }^{\#} P<0.01$ difference between treatments within a same genotype with two-way ANOVA and Bonferroni post hoc test (E and H), or with two-way ANOVA of repeated measures (L). Adrb1=adrenergic-beta1-receptor, Adrb2 = adrenergic-beta2receptor, $Y 1 r=Y 1$-receptor, $E E=$ energy expenditure, $\mathrm{RER}=$ respiratory exchange ratio, WT=wild-type mice, OE-NPY=OE-NPYDBH mice.

Table 7 Glucose metabolism in Y1R-antagonist treated OE-NPYDBH mice.

\begin{tabular}{|c|c|c|c|c|}
\hline & \multicolumn{2}{|c|}{ WT } & \multicolumn{2}{|c|}{ OE-NPYDBH } \\
\hline & Vehicle & Y1R & Vehicle & Y1R \\
\hline Glucose (mmol L-1) & $7.76 \pm 0.38$ & $7.45 \pm 0.46$ & $8.29 \pm 0.46$ & $8.51 \pm 0.39$ \\
\hline Insulin ( $\left.\mu \mathrm{g} \mathrm{L}^{-1}\right)$ & $0.28 \pm 0.03$ & $0.30 \pm 0.05$ & $0.47 \pm 0.04 * *$ & $0.51 \pm 0.07$ \\
\hline HOMA-IR & $2.54 \pm 0.34$ & $3.04 \pm 0.60$ & $4.30 \pm 0.44 * *$ & $5.72 \pm 1.04$ \\
\hline HOMA-B (\%) & $37.96 \pm 7.84$ & $38.49 \pm 8.10$ & $42.03 \pm 4.68$ & $39.56 \pm 5.17$ \\
\hline QUICKY & $0.33 \pm 0.01$ & $0.34 \pm 0.01$ & $0.31 \pm 0.01 *$ & $0.31 \pm 0.01$ \\
\hline
\end{tabular}

Glucose metabolism parametres were measured from 6-month-old homozygous male OE-NPYDBH vs wild-type mice ( $n=10-13 / g$ roup) treated with Y1R-antagonist (BIBO3044) or vehicle for 4 weeks. Values are expressed as means \pm S.E.M. ${ }^{*} P<0.05$ and $* * P<0.01$ between genotypes in vehicle treated groups with Student's t-test.

http://joe.endocrinology-journals.org DOI: 10.1530/JOE-16-0223
๑) 2017 Society for Endocrinology Printed in Great Britain
Published by Bioscientifica Ltd 
However, decreased Adrb1 expression points to suppressed sympathetic action in the liver, which may explain the locally induced metabolic changes. Low catecholamines have been reported to increase lipogenesis in WAT, and Adrb1 deficiency to induce IGT and IR, and to increase susceptibility to obesity and hepatosteatosis on a high fat diet (Ueta et al. 2012) providing additional support for our theory.

In conclusion, OE-NPYDBH mice develop obesity, IGT, IR, hepatosteatosis and hypercholesterolemia, and when pancreatic insulin production is disrupted, also T2D. The model reveals that NPY expressed in the noradrenergic neurons has potent metabolic effects in the WAT and the liver, which support energy conservation and storage. Our results suggest that the effects on WAT and liver are mediated mostly via inhibition of SNS in OE-NPYDBH mice, and that peripheral Y1-receptor mediated actions are less important, at least in the liver. The findings from OE-NPYDBH mice may be relevant to the mechanisms of stress-induced obesity and the metabolic disorders associated with the gain-of-function NPY polymorphisms.

\section{Supplementary data}

This is linked to the online version of the paper at http://dx.doi.org/10.1530/ JOE-16-0223.

\section{Declaration of interest}

The authors declare that there is no conflict of interest that could be perceived as prejudicing the impartiality of the research reported.

\section{Funding}

This study was supported by Academy of Finland (130882/2009, 252441/2011), the Finnish Funding Agency for Innovation (40098/10), State Funding for University-level Health Research, European Foundation for the Study of Diabetes and Finnish Foundation for Diabetes Research.

\section{Acknowledgements}

The authors thank Dr. Saku Ruohonen, Dr. Diana Toivola, Katariina Pohjanoksa, Satu Mäkelä, Sanna Bastman, Paulina Chrusciel, Raija Kaartosalmi, Elina Kahra and Hanna Haukkala for their scientific and technical assistance.

\section{References}

Ahotupa M, Mantyla E \& Kangas L 1997 Antioxidant properties of the triphenylethylene antiestrogen drug toremifene. NaunynSchmiedeberg's Archives of Pharmacology 356 297-302. (doi:10.1007/ pl00005054)
Assimacopoulos-Jeannet F, Brichard S, Rencurel F, Cusin I \& Jeanrenaud B 1995 In vivo effects of hyperinsulinemia on lipogenic enzymes and glucose transporter expression in rat liver and adipose tissues. Metabolism 44 228-233. (doi:10.1016/0026-0495(95)90270-8)

Bruinstroop E, Pei L, Ackermans MT, Foppen E, Borgers AJ, Kwakkel J, Alkemade A, Fliers E \& Kalsbeek A 2012 Hypothalamic neuropeptide $\mathrm{Y}$ (NPY) controls hepatic VLDL-triglyceride secretion in rats via the sympathetic nervous system. Diabetes 61 1043-1050. (doi:10.2337/ db11-1142)

Cabezas J, Mayorga M \& Crespo J 2012 Nonalcoholic fatty liver disease: A pathological view. In Liver Biopsy - Indications, Procedures, Results, pp 161-188. Eds N Takaya. Croatia: InTech.

Cho YR \& Kim CW 2004 Neuropeptide Y promotes beta-cell replication via extracellular signal-regulated kinase activation. Biochemical and Biophysical Research Communications 314 773-780. (doi:10.1016/j. bbrc.2003.12.170)

Corongiu FP \& Milia A 1983 An improved and simple method for determining diene conjugation in autoxidized polyunsaturated fatty acids. Chemico-Biological Interactions 44 289-297. (doi:10.1016/00092797(83)90056-X)

Dagdeviren S, Jung DY, Lee E, Friedline RH, Noh HL, Kim JH, Patel PR, Tsitsilianos N, Tsitsilianos AV, Tran DA, et al. 2016 Altered interleukin-10 signaling in skeletal muscle regulates obesity-mediated inflammation and insulin resistance. Molecular and Cellular Biology 36 2956-2966. (doi:10.1128/МСВ.00181-16)

Donnelly KL, Smith CI, Schwarzenberg SJ, Jessurun J, Boldt MD \& Parks EJ 2005 Sources of fatty acids stored in liver and secreted via lipoproteins in patients with nonalcoholic fatty liver disease. Journal of Clinical Investigation 115 1343-1351. (doi:10.1172/JCI23621)

Dozio E, Ruscica M, Motta M \& Magni P 2007 Hypothalamic neuropeptide systems as targets for potential anti-obesity drugs. Mini Reviews in Medicinal Chemistry 7 11-19. (doi:10.2174/138955707779 317894)

Egawa M, Yoshimatsu H \& Bray GA 1991 Neuropeptide Y suppresses sympathetic activity to interscapular brown adipose tissue in rats. American Journal of Physiology 260 R328-R334.

Ekblad E, Edvinsson L, Wahlestedt C, Uddman R, Hakanson R \& Sundler F 1984 Neuropeptide Y co-exists and co-operates with noradrenaline in perivascular nerve fibers. Regulatory peptides 8 225-235. (doi:10.1016/0167-0115(84)90064-8)

Ferreira R, Xapelli S, Santos T, Silva AP, Cristovao A, Cortes L \& Malva JO 2010 Neuropeptide Y modulation of interleukin-1 1 beta\} (IL-1 beta\})-induced nitric oxide production in microglia. Journal of Biological Chemistry 285 41921-41934. (doi:10.1074/jbc. M110.164020)

Folch J, Lees M \& Sloane Stanley GH 1957 A simple method for the isolation and purification of total lipides from animal tissues. The Journal of Biological Chemistry 226 497-509.

Fu Y, Luo L, Luo N \& Garvey WT 2006 Proinflammatory cytokine production and insulin sensitivity regulated by overexpression of resistin in 3T3-L1 adipocytes. Nutrition \& Metabolism 328.

Gao S, He L, Ding Y \& Liu G 2010 Mechanisms underlying different responses of plasma triglyceride to high-fat diets in hamsters and mice: Roles of hepatic MTP and triglyceride secretion. Biochemical and Biophysical Research Communications 398 619-626. (doi:10.1016/j. bbrc.2010.05.114)

Gilbert ER, Fu Z \& Liu D 2011 Development of a nongenetic mouse model of type 2 diabetes. Experimental Diabetes Research 2011416254. (doi:10.1155/2011/416254)

Gylling H, Hallikainen M, Kolehmainen M, Toppinen L, Pihlajamaki J, Mykkanen H, Agren JJ, Rauramaa R, Laakso M \& Miettinen TA 2007 Cholesterol synthesis prevails over absorption in metabolic syndrome. Translational Research 149 310-316. (doi:10.1016/j. trsl.2006.11.012)

Hundal RS, Krssak M, Dufour S, Laurent D, Lebon V, Chandramouli V, Inzucchi SE, Schumann WC, Petersen KF, Landau BR, et al. 2000

Published by Bioscientifica Ltd. 
Mechanism by which metformin reduces glucose production in type 2 diabetes. Diabetes 49 2063-2069. (doi:10.2337/ diabetes.49.12.2063)

Jaakkola U, Kallio J, Heine RJ, Nijpels G, T’Hart LM, Maassen JA, Bouter LM, Stehouwer CD \& Dekker JM 2009 Neuropeptide Y polymorphism significantly magnifies diabetes and cardiovascular disease risk in obesity: The hoorn study. European Journal of Clinical Nutrition 63 150-152. (doi:10.1038/sj.ejcn.1602964)

Kallio J, Pesonen U, Kaipio K, Karvonen MK, Jaakkola U, Heinonen OJ, Uusitupa MI \& Koulu M 2001 Altered intracellular processing and release of neuropeptide $Y$ due to leucine 7 to proline 7 polymorphism in the signal peptide of preproneuropeptide $\mathrm{Y}$ in humans. FASEB Journal 15 1242-1244.

Karvonen MK, Ruottinen S, Koulu M, Pesonen U, Niinikoski H, RaskNissila L, Simell O \& Ronnemaa T 2006 Nutrient intake, weight, and Leu7Pro polymorphism in prepro-neuropeptide Y in children. Journal of Clinical Endocrinology and Metabolism 91 4664-4668. (doi:10.1210/ jc.2005-2083)

Karvonen MK, Pesonen U, Koulu M, Niskanen L, Laakso M, Rissanen A, Dekker JM, Hart LM, Valve R \& Uusitupa MI 1998 Association of a leucine(7)-to-proline(7) polymorphism in the signal peptide of neuropeptide Y with high serum cholesterol and LDL cholesterol levels. Nature Medicine 4 1434-1437. (doi:10.1038/4027)

Karvonen MK, Valkonen VP, Lakka TA, Salonen R, Koulu M, Pesonen U, Tuomainen TP, Kauhanen J, Nyyssonen K, Lakka HM, et al. 2001 Leucine7 to proline7 polymorphism in the preproneuropeptide $\mathrm{Y}$ is associated with the progression of carotid atherosclerosis, blood pressure and serum lipids in finnish men. Atherosclerosis 159 145-151. (doi:10.1016/S0021-9150(01)00468-3)

Kozarsky KF, Donahee MH, Glick JM, Krieger M \& Rader DJ 2000 Gene transfer and hepatic overexpression of the HDL receptor SR-BI reduces atherosclerosis in the cholesterol-fed LDL receptor-deficient mouse. Arteriosclerosis, Thrombosis, and Vascular Biology 20 721-727. (doi:10.1161/01.ATV.20.3.721)

Kuo LE, Kitlinska JB, Tilan JU, Li L, Baker SB, Johnson MD, Lee EW, Burnett MS, Fricke ST, Kvetnansky R, et al. 2007 Neuropeptide Y acts directly in the periphery on fat tissue and mediates stress-induced obesity and metabolic syndrome. Nature Medicine 13 803-811. (doi:10.1038/nm1611)

Lee DH, Jacobs DR, Jr, Gross M, Kiefe CI, Roseman J, Lewis CE \& Steffes M 2003 Gamma-glutamyltransferase is a predictor of incident diabetes and hypertension: The coronary artery risk development in young adults (CARDIA) study. Clinical Chemistry 49 1358-1366. (doi:10.1373/49.8.1358)

Lu H, Liu H, Hu F, Zou L, Luo S \& Sun L 2013 Independent association between nonalcoholic fatty liver disease and cardiovascular disease: A systematic review and meta-analysis. International Journal of Endocrinology 2013124958

Machida Y, Bruinsma C, Hallinger DR, Roper SM, Garcia E, Trevino MB, Nadler J, Ahima R \& Imai Y 2014 Pancreatic islet neuropeptide $\mathrm{Y}$ overexpression has minimal effect on islet morphology and beta-cell adaptation to high-fat diet. Endocrinology 155 4634-4640. (doi:10.1210/en.2014-1537)

Masoudi-Kazemabad A, Jamialahmadi K, Moohebati M, Mojarrad M, Manshadi RD, Akhlaghi S, Ferns GA \& GhayourMobarhan M 2013 Neuropeptide Y Leu7Pro polymorphism associated with the metabolic syndrome and its features in patients with coronary artery disease. Angiology 64 40-45. (doi:10.1177/0003319711435149)

Matsuzawa-Nagata N, Takamura T, Ando H, Nakamura S, Kurita S, Misu H, Ota T, Yokoyama M, Honda M, Miyamoto K, et al. 2008 Increased oxidative stress precedes the onset of high-fat diet-induced insulin resistance and obesity. Metabolism 57 1071-1077. (doi:10.1016/j. metabol.2008.03.010)

McTernan PG, Fisher FM, Valsamakis G, Chetty R, Harte A, McTernan CL, Clark PM, Smith SA, Barnett AH \& Kumar S 2003 Resistin and

http://joe.endocrinology-journals.org

DOI: $10.1530 / \mathrm{JOE}-16-0223$
๑ 2017 Society for Endocrinology Printed in Great Britain type 2 diabetes: Regulation of resistin expression by insulin and rosiglitazone and the effects of recombinant resistin on lipid and glucose metabolism in human differentiated adipocytes. Journal of Clinical Endocrinology and Metabolism 88 6098-6106. (doi:10.1210/ jc.2003-030898)

Mitchell GC, Wang Q, Ramamoorthy P \& Whim MD 2008 A common single nucleotide polymorphism alters the synthesis and secretion of neuropeptide Y. Journal of Neuroscience 28 14428-14434. (doi:10.1523/ JNEUROSCI.0343-08.2008)

Nishina PM, Lowe S, Wang J \& Paigen B 1994 Characterization of plasma lipids in genetically obese mice: The mutants obese, diabetes, fat, tubby, and lethal yellow. Metabolism 43 549-553. (doi:10.1016/00260495(94)90194-5)

Nordman S, Ding B, Ostenson CG, Karvestedt L, Brismar K, Efendic S \& Gu HF 2005 Leu7Pro polymorphism in the neuropeptide Y (NPY) gene is associated with impaired glucose tolerance and type 2 diabetes in swedish men. Experimental and Clinical Endocrinology \& Diabetes 113 282-287. (doi:10.1055/s-2005-865650)

Paredes-Turrubiarte G, Gonzalez-Chavez A, Perez-Tamayo R, SalazarVazquez BY, Hernandez VS, Garibay-Nieto N, Fragoso JM \& Escobedo G 2016 Severity of non-alcoholic fatty liver disease is associated with high systemic levels of tumor necrosis factor alpha and low serum interleukin 10 in morbidly obese patients. Clinical and Experimental Medicine 16 193-202. (doi:10.1007/s10238-0150347-4)

Pihlajamaki J, Karhapaa P, Vauhkonen I, Kekalainen P, Kareinen A, Viitanen L, Pesonen U, Kallio J, Uusitupa M \& Laakso M 2003 The Leu7Pro polymorphism of the neuropeptide Y gene regulates free fatty acid metabolism. Metabolism 52 643-646. (doi:10.1053/ meta.2003.50098)

Rajala MW, Obici S, Scherer PE \& Rossetti L 2003 Adipose-derived resistin and gut-derived resistin-like molecule-beta selectively impair insulin action on glucose production. Journal of Clinical Investigation 111 225-230. (doi:10.1172/JCI16521)

Roberts LJ \& Morrow JD 2000 Measurement of F(2)-isoprostanes as an index of oxidative stress in vivo. Free Radical Biology \& Medicine $\mathbf{2 8}$ 505-513. (doi:10.1016/s0891-5849(99)00264-6)

Ruohonen ST, Vahatalo LH \& Savontaus E 2012 Diet-induced obesity in mice overexpressing neuropeptide y in noradrenergic neurons. International Journal of Peptides 2012452524. (doi:10.1155/2012/452524)

Ruohonen ST, Pesonen U, Moritz N, Kaipio K, Roytta M, Koulu M \& Savontaus E 2008 Transgenic mice overexpressing neuropeptide Y in noradrenergic neurons: A novel model of increased adiposity and impaired glucose tolerance. Diabetes 57 1517-1525. (doi:10.2337/ db07-0722)

Shetty GK, Economides PA, Horton ES, Mantzoros CS \& Veves A 2004 Circulating adiponectin and resistin levels in relation to metabolic factors, inflammatory markers, and vascular reactivity in diabetic patients and subjects at risk for diabetes. Diabetes Care 27 2450-2457. (doi:10.2337/diacare.27.10.2450)

Shi YC, Lin S, Castillo L, Aljanova A, Enriquez RF, Nguyen AD, Baldock PA, Zhang L, Bijker MS, Macia L, et al. 2011 Peripheral-specific y2 receptor knockdown protects mice from high-fat diet-induced obesity. Obesity 19 2137-2148. (doi:10.1038/oby.2011.99)

Shi YC, Lau J, Lin Z, Zhang H, Zhai L, Sperk G, Heilbronn R, Mietzsch M, Weger S, Huang XF, et al. 2013 Arcuate NPY controls sympathetic output and BAT function via a relay of tyrosine hydroxylase neurons in the PVN. Cell Metabolism 17 236-248. (doi:10.1016/j. cmet.2013.01.006)

Sigala B, McKee C, Soeda J, Pazienza V, Morgan M, Lin CI, Selden C, Vander Borght S, Mazzoccoli G, Roskams T, et al. 2013 Sympathetic nervous system catecholamines and neuropeptide $Y$ neurotransmitters are upregulated in human NAFLD and modulate the fibrogenic function of hepatic stellate cells. PloS One $\mathbf{8}$ e72928. (doi:10.1371/journal.pone.0072928) 
Simonen P, Kotronen A, Hallikainen M, Sevastianova K, Makkonen J, Hakkarainen A, Lundbom N, Miettinen TA, Gylling H \& Yki-Jarvinen H 2011 Cholesterol synthesis is increased and absorption decreased in non-alcoholic fatty liver disease independent of obesity. Journal of Hepatology 54 153-159. (doi:10.1016/j.jhep.2010.05.037)

Sousa-Ferreira L, Garrido M, Nascimento-Ferreira I, Nobrega C, SantosCarvalho A, Alvaro AR, Rosmaninho-Salgado J, Kaster M, Kugler S, de Almeida LP, et al. 2011 Moderate long-term modulation of neuropeptide Y in hypothalamic arcuate nucleus induces energy balance alterations in adult rats. PloS One 6 e22333. (doi:10.1371/ journal.pone.0022333)

Stafford JM, Yu F, Printz R, Hasty AH, Swift LL \& Niswender KD 2008 Central nervous system neuropeptide $\mathrm{Y}$ signaling modulates VLDL triglyceride secretion. Diabetes 57 1482-1490. (doi:10.2337/db071702)

Steppan CM, Bailey ST, Bhat S, Brown EJ, Banerjee RR, Wright CM, Patel HR, Ahima RS \& Lazar MA 2001 The hormone resistin links obesity to diabetes. Nature 409 307-312. (doi:10.1038/35053000)

Targher G, Bertolini L, Poli F, Rodella S, Scala L, Tessari R, Zenari L \& Falezza G 2005 Nonalcoholic fatty liver disease and risk of future cardiovascular events among type 2 diabetic patients. Diabetes $\mathbf{5 4}$ 3541-3546. (doi:10.2337/diabetes.54.12.3541)

Ueta CB, Fernandes GW, Capelo LP, Fonseca TL, Maculan FD, Gouveia CH, Brum PC, Christoffolete MA, Aoki MS, Lancellotti CL, et al. 2012 Beta(1) adrenergic receptor is key to cold- and diet-induced thermogenesis in mice. Journal of Endocrinology 214 359-365. (doi:10.1530/JOE-12-0155)

Ukkola O \& Kesaniemi YA 2007 Leu7Pro polymorphism of PreproNPY associated with an increased risk for type II diabetes in middleaged subjects. European Journal of Clinical Nutrition 61 1102-1105. (doi:10.1038/sj.ejcn.1602621)

Vahatalo LH, Ruohonen ST, Makela S, Kovalainen M, Huotari A, Makela KA, Maatta JA, Miinalainen I, Gilsbach R, Hein L, et al. 2014 Neuropeptide $\mathrm{Y}$ in the noradrenergic neurones induces obesity and inhibits sympathetic tone in mice. Acta Physiologica 213 902-919. (doi:10.1111/apha.12436)

van Rossum CT, Pijl H, Adan RA, Hoebee B \& Seidell JC 2006 Polymorphisms in the NPY and AGRP genes and body fatness in dutch adults. International Journal of Obesity 30 1522-1528. (doi:10.1038/sj.ijo.0803314)

Vozarova B, Stefan N, Lindsay RS, Saremi A, Pratley RE, Bogardus C \& Tataranni PA 2002 High alanine aminotransferase is associated with decreased hepatic insulin sensitivity and predicts the development of type 2 diabetes. Diabetes 51 1889-1895. (doi:10.2337/ diabetes.51.6.1889)
Wheway J, Mackay CR, Newton RA, Sainsbury A, Boey D, Herzog H \& Mackay F 2005 A fundamental bimodal role for neuropeptide Y1 receptor in the immune system. Journal of Experimental Medicine 202 1527-1538. (doi:10.1084/jem.20051971)

Xie F, Zhang R, Yang C, Xu Y, Wang N, Sun L, Liu J, Sun L, Wei $\mathrm{R} \&$ Ai J 2012 Long-term neuropeptide Y administration in the periphery induces abnormal baroreflex sensitivity and obesity in rats. Cellular Physiology and Biochemistry 29 111-120. (doi:10.1159/000337592)

Yang L, Scott KA, Hyun J, Tamashiro KL, Tray N, Moran TH \& Bi S 2009 Role of dorsomedial hypothalamic neuropeptide $\mathrm{Y}$ in modulating food intake and energy balance. Journal of Neuroscience 29 179-190. (doi:10.1523/JNEUROSCI.4379-08.2009)

Yeung EH, Zhang C, Chen J, Bowers K, Hu FB, Kang G \& Qi L 2011 Polymorphisms in the neuropeptide $\mathrm{Y}$ gene and the risk of obesity: Findings from two prospective cohorts. Journal of Clinical Endocrinology and Metabolism 96 E2055-E2062. (doi:10.1210/jc.20110195)

Yuzuriha H, Inui A, Asakawa A, Ueno N, Kasuga M, Meguid MM, Miyazaki J, Ninomiya M, Herzog H \& Fujimiya M 2007. Gastrointestinal hormones (anorexigenic peptide YY and orexigenic ghrelin) influence neural tube development. FASEB Journal 21 2108-2112. (doi:10.1096/fj.06-7621com)

Yuzuriha H, Inui A, Goto K, Asakawa A, Fujimiya M \& Kasuga M 2003 Intracerebroventricular administration of NPY stimulates resistin gene expression in mice. International Journal of Molecular Medicine 11 675-676.

Zarjevski N, Cusin I, Vettor R, Rohner-Jeanrenaud F \& Jeanrenaud B 1993 Chronic intracerebroventricular neuropeptide-Y administration to normal rats mimics hormonal and metabolic changes of obesity. Endocrinology 133 1753-1758. (doi:10.1210/ endo.133.4.8404618)

Zhang L, Lee IC, Enriquez RF, Lau J, Vahatalo LH, Baldock PA, Savontaus E \& Herzog H 2014 Stress- and diet-induced fat gain is controlled by NPY in catecholaminergic neurons. Molecular Metabolism 3 581-591. (doi:10.1016/j.molmet.2014.05.001)

Zhang L, Macia L, Turner N, Enriquez RF, Riepler SJ, Nguyen AD, Lin S, Lee NJ, Shi YC, Yulyaningsih E, et al. 2010 Peripheral neuropeptide Y Y1 receptors regulate lipid oxidation and fat accretion. International Journal of Obesity 34 357-373. (doi:10.1038/ijo.2009.232)

Zhu X, Gillespie DG \& Jackson EK 2015 NPY1-36 and PYY1-36 activate cardiac fibroblasts: An effect enhanced by genetic hypertension and inhibition of dipeptidyl peptidase 4. American Journal of Physiology: Heart and Circulatory Physiology 309 H1528-H1542. (doi:10.1152/ ajpcell.00090.2015)

Received in final form 28 March 2017

Accepted 3 May 2017

Accepted Preprint published online 3 May 2017 http://joe.endocrinology-journals.org

DOI: 10.1530/JOE-16-0223
๑) 2017 Society for Endocrinology Printed in Great Britain
Published by Bioscientifica Ltd. 